\title{
Molecular Subtypes and Tumor Response to Neoadjuvant Chemotherapy in Patients with Locally Advanced Breast Cancer
}

\author{
Seung II Kim ${ }^{a}$ Joohyuk Sohn ${ }^{b}$ Ja Seung Koo ${ }^{c}$ Se Ho Park ${ }^{a}$ Hyung Seok Park ${ }^{a}$ \\ Byeong Woo Park ${ }^{a, d}$
}

Departments of a Surgery, ${ }^{b}$ Medical Oncology, and ${ }^{\mathrm{c} P a t h o l o g y, ~ a n d ~ d ~ B r a i n ~ K o r e a ~} 21$ Project, Yonsei University

College of Medicine, Seoul, Korea

\section{Key Words}

Breast cancer $\cdot$ Molecular subtype $\cdot$ Neoadjuvant

chemotherapy $\cdot$ Pathologic complete response

\begin{abstract}
Objective: Pathologic complete response $(p C R)$ is the most predictive factor for patients with neoadjuvant chemotherapy and we investigated the rate of pCR according to molecular subtypes defined by immunohistochemical staining. Methods: Our subjects comprised 257 breast cancer patients who received 3 cycles of anthracycline/taxane-based neoadjuvant chemotherapy. The patients were classified into 4 subtypes: luminal A, luminal B, HER2 and triple negative. We analyzed the $\mathrm{pCR}$ rate and treatment outcome according to these subtypes. Results: Of a total of 257 patients, the $\mathrm{PCR}$ rate of luminal A, luminal $\mathrm{B}, \mathrm{HER} 2$ and triple negative was $3.9,5.0,10.5$ and $21.1 \%$, respectively $(p=0.001)$. The 5 -year disease-free survival of the pCR group (88.4\%) was higher than that of the non-pCR group (65.6\%), but it was not significant $(p=0.228)$. Among patients who have residual disease, the 5-year disease-free survival of luminal A, luminal $B$, HER2 and triple negative was $64.0,65.7,75.2$ and $66.5 \%$, respectively $(p=0.243)$. Triple negative and HER2 subtypes
\end{abstract}

are more sensitive to neoadjuvant chemotherapy. Conclusion: To increase the $p C R$ rate, type-specific approaches according to subtypes, such as an addition of trastuzumab, increasing the number of cycles or a novel regimen, should be considered.

Copyright $\odot 2011$ S. Karger AG, Basel

\section{Introduction}

Neoadjuvant chemotherapy (NCT) has become a primary option for patients with locally advanced breast cancer [1]. The rationale for NCT is to improve surgical options $[2,3]$ and to gain information on drug response by in-breast assessment. Furthermore, NCT provides the opportunity to discover predictive markers of chemotherapy.

The pathologic complete response (pCR) after NCT is probably most predictive with respect to long-term treatment outcomes [4-6]. The results of early-generation clinical trials revealed that patients with locally advanced breast cancer who achieved a PCR have a good prognosis, while those who had a residual disease showed worse treatment outcomes [4]. Another interesting observation

\section{KARGER}

Fax +4161306 1234 E-Mail karger@karger.ch www.karger.com
(C) 2011 S. Karger AG, Basel 0030-2414/10/0796-0324\$26.00/0

Accessible online at:

www.karger.com/ocl
Byeong-Woo Park, MD, PhD

Department of Surgery

Yonsei University College of Medicine

134 Shinchon-dong, Seodaemun-gu, Seoul (Korea)

Tel. +82 22228 2121, Fax +82 2313 8289, E-Mail bwpark@yuhs.ac 
from NCT trials was that some tumor clinicopathologic characteristics can be used as a predictor of the likelihood of $\mathrm{pCR}$. The prediction of the possibility of pCR before starting NCT is an important research goal in order to maximize the treatment effect and minimize unnecessary toxicity [7].

Breast cancer has recently been shown to be divided into distinct molecular subtypes (luminal A, luminal B, HER 2 and triple negative) by gene expression profiling with prognostic significance [8-10]. For practical issue in hospital setting, immunohistochemical surrogate panels of estrogen receptor (ER), progesterone receptor (PR) and HER2 have been proposed to potentially discriminate the subtypes as a substitution of gene expression profiling [11-15]. We hypothesized that the distinct molecular subtype defined by ER, PR and HER 2 might have a different response to NCT. To investigate the relationship between the provability of $\mathrm{pCR}$ and molecular subtypes, we designed this study.

\section{Patients and Methods}

\section{Study Population}

The patient cohort of the present study was histologically confirmed with primary breast cancer and received neoadjuvant adriamycin $\left(50 \mathrm{mg} / \mathrm{m}^{2}\right.$, day 1$)$ plus docetaxel $\left(75 \mathrm{mg} / \mathrm{m}^{2}\right.$, day 1$)$ chemotherapy (AT) every 3 weeks for 3 cycles from January 2004 to December 2008 at Severance Hospital, Yonsei University College of Medicine, Seoul, Korea. After NCT, all patients underwent definitive surgery including an axillary lymph node dissection followed by a subsequent 3 cycles of adjuvant AT chemotherapy and radiation therapy. All but 1 patient with luminal subtypes also received adjuvant endocrine therapy followed by 3 cycles of adjuvant AT chemotherapy. Because trastuzumab for the HER2positive breast cancer was not covered by health insurance until 2009 , herceptin was not utilized.

262 consecutive locally advanced breast cancer patients met the above criteria. The surgical specimens were entirely submitted for routine pathologic evaluation. Among them, 257 (98.1\%) cases were available for all information on ER, PR and HER2 status. Five $(1.9 \%)$ cases were excluded primarily because of incomplete information on ER, PR and HER2 status for classification of molecular subtypes.

We retrospectively reviewed the clinicopathological data including age, clinical $\mathrm{T}$ stage, clinical $\mathrm{N}$ stage, histologic type, $\mathrm{pCR}$ rate to NCT, and follow-up data. All data were extracted from the Severance Hospital Breast Cancer Registry which is a prospectively maintained database that includes clinical information, pathologic information, treatment modality and details of outcome.

\section{Classification of Molecular Subtypes}

We used an immunohistochemistry and/or fluorescence in situ hybridization (FISH) assay for 3 surrogate markers of ER, PR and HER2. Immunohistochemistry was performed for ER (SP1, Thermo Scientific, Fremont, Calif., USA), PR (PgR636, Dako,
Table 1. Classification and distribution of breast cancer subtype by ER, PR and HER2 status

\begin{tabular}{lllrc}
\hline Subtype & ER and/or PR & HER2 & \multicolumn{1}{c}{$\mathrm{n}$} & $\%$ \\
\hline Luminal A & positive & negative & 103 & 40.1 \\
Luminal B & positive & positive & 40 & 15.6 \\
HER2 & negative & positive & 38 & 14.8 \\
Triple negative & negative & negative & 76 & 29.6 \\
\hline Total & & & 257 & 100
\end{tabular}

Glostrup, Denmark) and HER2 (Dako) as a routine clinical diagnostic procedure. The cutoff values for ER and PR were $10 \%$ positive cells, irrespective of intensity. HER2 staining was scored according to the American Society of Clinical Oncology/College of American Pathologists guideline [16]. FISH analysis (Vysis Pathvision c-erbB2 probe and Dako FISH histology accessory kit) was performed manually, and the evaluation of signals was carried out according to the Vysis manual.

The study population was grouped into 4 subtypes: luminal A (ER and/or PR positive, HER2 negative), luminal B (ER and/or PR positive, HER2 positive), HER2 (ER and PR negative, HER2 positive) and triple negative (ER negative, $\mathrm{PR}$ negative and HER2 negative).

Study Endpoint and Statistics

The primary endpoint of this study was the pCR rate according to molecular subtypes. The pCR was defined as disappearance of all invasive cancer in the breast and axilla after NCT [17]. Patients with residual ductal carcinoma in situ were also considered as pCR [18]. The pCR rates were calculated for each molecular subtype and the Fisher exact test was used to evaluate the relationship between subtypes and the pCR rate.

The secondary endpoint was disease-free survival (DFS) among patients who had a residual disease. First, we compared the 5 -year DFS rate of the pCR and non-pCR groups. Second, we compared the difference of the 5-year DFS among patients with residual disease. DFS was calculated as the time from the date of surgery to the date of the development of local, regional and distant metastases, and the date of death before recurrence. DFS estimation was performed according to the Kaplan-Meier method, and the comparison of the groups was based on a log-rank test. All reported $p$ values are 2 -sided, and $p$ values $<0.05$ were considered significant.

\section{Results}

Patient Characteristics and Distribution of Molecular Subtypes

Patient characteristics and distribution of molecular subtypes are summarized in tables 1 and 2 . The luminal A, luminal B, HER2 and triple negative subtype accounted for 103 (40.1\%), 40 (15.6\%), 38 (14.8\%) and 76 cases 
Table 2. Patient characteristics

\begin{tabular}{|c|c|c|c|c|c|c|}
\hline & & $\begin{array}{l}\text { Luminal } \\
\text { A }\end{array}$ & $\begin{array}{l}\text { Luminal } \\
\mathrm{B}\end{array}$ & HER2 & $\begin{array}{l}\text { Triple } \\
\text { negative }\end{array}$ & $\mathrm{p}$ \\
\hline \multirow[t]{2}{*}{ Age $(n=257)$} & $\leq 50$ years & $73(70.9)$ & $28(70.0)$ & $16(42.1)$ & $49(64.5)$ & \multirow[t]{2}{*}{0.014} \\
\hline & $>50$ years & $30(29.1)$ & $12(30.0)$ & $22(57.9)$ & $27(35.5)$ & \\
\hline \multirow[t]{3}{*}{ Clinical T $(\mathrm{n}=248)$} & 1 & $15(15.3)$ & $5(12.5)$ & $3(8.1)$ & $11(15.1)$ & \multirow[t]{3}{*}{$>0.05$} \\
\hline & 2 & $69(70.4)$ & $32(80.0)$ & $31(83.8)$ & $47(64.4)$ & \\
\hline & $>3$ & $14(14.3)$ & $3(7.5)$ & $3(8.1)$ & $15(20.5)$ & \\
\hline \multirow[t]{2}{*}{ Clinical N $(n=257)$} & negative & $3(2.9)$ & $1(2.5)$ & $3(7.9)$ & $7(9.2)$ & \multirow[t]{2}{*}{$>0.05$} \\
\hline & positive & $100(97.1)$ & $39(97.5)$ & $35(92.1)$ & $69(90.8)$ & \\
\hline \multirow[t]{3}{*}{ Histologic type $(\mathrm{n}=252)$} & ductal & $94(94.0)$ & $35(87.5)$ & $33(89.2)$ & $67(89.3)$ & \multirow[t]{3}{*}{$>0.05$} \\
\hline & lobular & $3(3.0)$ & $0(0.0)$ & $1(2.7)$ & $0(0.0)$ & \\
\hline & other & $3(3.0)$ & $5(12.5)$ & $3(8.1)$ & $8(10.7)$ & \\
\hline \multirow[t]{2}{*}{ Type of surgery $(\mathrm{n}=257)$} & BCT & $10(9.7)$ & $7(17.5)$ & $3(7.9)$ & $19(25.0)$ & \multirow[t]{2}{*}{0.02} \\
\hline & mastectomy & $93(90.3)$ & $33(82.5)$ & $35(92.1)$ & $57(75.0)$ & \\
\hline
\end{tabular}

Figures in parentheses are percentages. BCT $=$ Breast conservation therapy.

Table 3. pCR rate according to clinicopathologic characteristics

\begin{tabular}{lcccc}
\hline Subtype & Total & No pCR & pCR & p \\
\hline Luminal A & 103 & $99(96.1)$ & $4(3.9)$ & 0.001 \\
Luminal B & 40 & $38(95.0)$ & $2(5.0)$ & \\
HER2 & 38 & $34(89.5)$ & $4(10.5)$ & \\
Triple negative & 76 & $60(78.9)$ & $16(21.1)$ & \\
\hline Total & 257 & $231(89.9)$ & $26(10.1)$ & \\
\hline
\end{tabular}

Figures in parentheses are percentages.

(29.6\%), respectively (table 1). The 4 molecular subtypes did not differ significantly by clinical T stage, clinical axillary node status and histologic type (all $\mathrm{p}>0.05)$, while patients with a HER 2 type were older than other subtypes $(\mathrm{p}=0.014)($ table 2$)$.

\section{pCR Rate according to Breast Cancer Subtypes}

Of the 257 patients tested, 26 patients achieved pCR; thus, the pCR rate was $10.1 \%$ (table 3 ). The rates of pCR differed significantly among the 4 molecular subtypes with 3.9\% (4/103) for luminal A, 5.0\% (2/40) for luminal B, 10.5\% (4/38) for HER2 and 21.1\% (16/76) for triple negative $(\mathrm{p}=0.001)$ (table 3$)$. The greatest difference of the pCR rate was observed between the triple negative and luminal A/B subtype. Breast conservation therapy was performed more frequently in patients with the triple negative than in those with other subtypes $(\mathrm{p}=0.02)(\mathrm{ta}-$ ble 2).

We also tested the association of the pCR rate and other clinicopathological variables such as age ( $\leq 50$ vs. $>50$ years), clinical T stage (T1 vs. T2 vs. $>$ T3), clinical N stage (negative vs. positive) and histologic type (ductal vs. luminal vs. other). There were no clinicopathological variables that were significantly correlated with pCR (data not shown).

\section{Survival Analysis}

The mean follow-up time for the present study cohort was 23.2 months (median 21.3), and 41 patients (16.0\%) relapsed during follow-up. The Kaplan-Meier survival estimation showed that the 5-year DFS of patients who achieved pCR was better than of those who had a residual invasive disease ( 88.4 vs. $65.6 \%$; absolute difference $22.8 \%$; $\mathrm{p}=0.228$ ), but the difference did not reach statistical significance, probably due to the small study population and the short follow-up period (fig. 1).

To compare the DFS between subtypes within the patients who had residual disease, we performed a survival analysis after excluding the patients who achieved pCR. The estimated 5-year DFS of luminal A, luminal B, HER2 and the triple negative subtype was $64.0,65.7,75.2$ and $66.5 \%$, respectively ( $\mathrm{p}=0.243$ ) (fig. 2 ). These results suggest that the DFS of patients who have a residual disease is poor regardless of subtypes. 


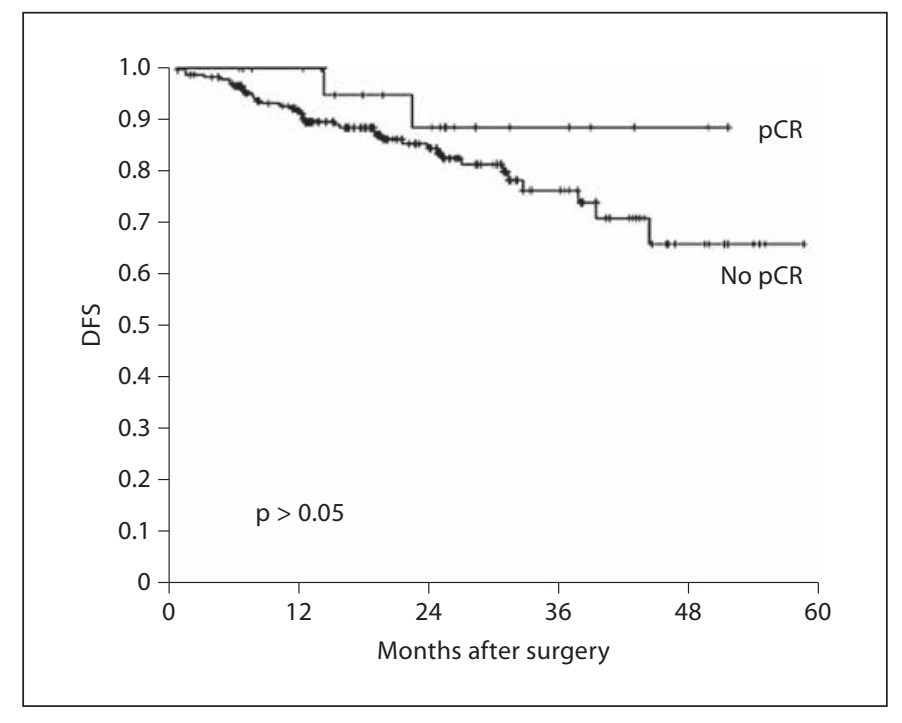

Fig. 1. Kaplan-Meier 5-year DFS estimation in patients with pCR and in those who had residual invasive disease.

\section{Discussion}

The results of the clinical trials revealed that $\mathrm{pCR}$ is related to good treatment outcomes and can be used as a surrogate marker of better survival [4-6]. Patients with a low chance of pCR might be spared unnecessary toxicity and allowed a chance of alternative treatment [7].

Gene expression studies have identified distinct molecular subtypes of breast cancer with a different prognosis [8-10]. It is believed that various subtypes of breast cancer not only have different prognoses but also show different sensitivities to systemic chemotherapy. Rouzier et al. [19] evaluated the gene expression profiles of patients treated with NCT and reported that the pCR rate was $45 \%$ for the basal-like and HER2-positive subtypes and $6 \%$ for the luminal tumors.

Although the original method to define the breast cancer molecular subtype is microarrays for gene expression analysis, subsequent work has shown that an immunohistochemical panel composed of 3-5 markers could serve as a proxy for breast cancer subtyping $[12,13,15$, 20], and there is increasing evidence that distinct subtypes defined by immunohistochemical markers differ in their response to chemotherapy. Recent reports using these markers revealed significantly higher pCR to NCT among the triple negative and HER2-positive/ER-negative subtypes compared with the luminal subtype $[15,20]$.

In the present study, we used similar molecular classifications that were previously reported $[15,20]$. The pri-

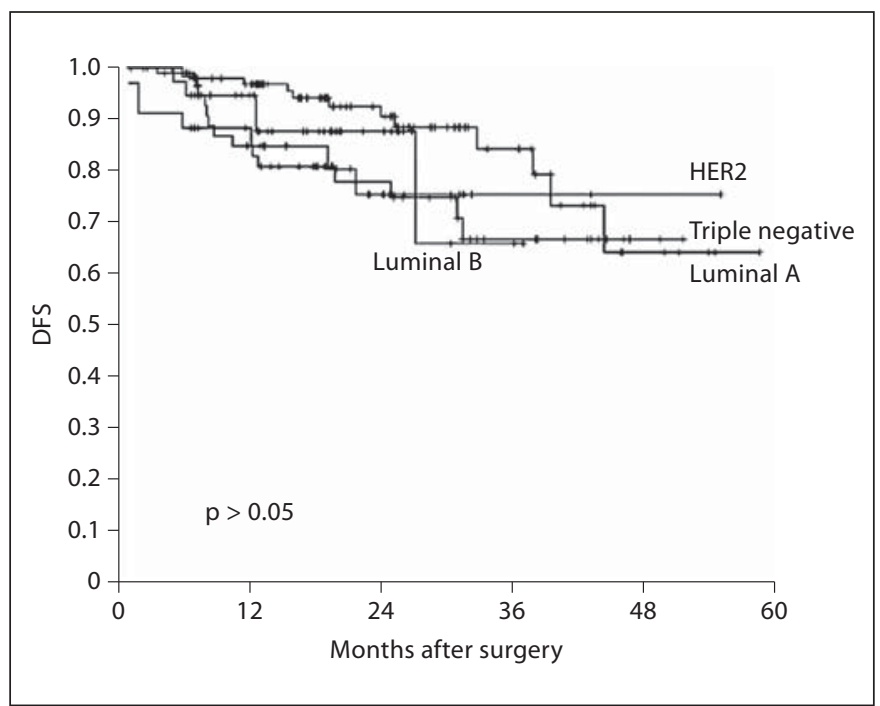

Fig. 2. Kaplan-Meier 5-year DFS estimation according to breast cancer subtype among patients who had residual invasive disease.

mary subdivision of molecular subtypes was by the ER status. The ER-positive tumors were subdivided into luminal A and luminal B according to the HER2 status. The ER-negative tumors were subdivided into the HER2 and triple negative subtypes. The pCR rate of the present study was slightly lower compared with other adriamycin-taxane-based neoadjuvant trials $[21,22]$. This difference is likely explained by split NCT with only 3 cycles before surgery. Nevertheless, we have also found that patients with the triple negative and HER2 subtype of breast cancer have a higher rate of $\mathrm{pCR}$ to NCT than the luminal subtype. As a consequence, breast conservation surgery was performed more often in patients with the triple negative subtype ( $\mathrm{p}=0.02)$ (table 2$)$.

There are multiple potential reasons that the response to chemotherapy differed by subtype. The triple negative and HER2-positive/ER-negative breast cancers are characterized by the high expression of the proliferation cluster of genes $[8,9]$. A prognostic index that is heavily influenced by proliferation genes was recently shown to predict pCR to doxorubicin/docetaxel primary chemotherapy [23]. Furthermore, the triple negative tumor is basically ER/PR negative, and evidence suggests that the negative hormone receptor status is one of the strongest predictive markers associated with the higher likelihood of pCR to NCT [24-26].

In the present study, we confirmed previous observations that patients who had a pCR to NCT had a good prognosis $[27,28]$. Although the DFS of patients with PCR 
and non-pCR was not significantly different because of the short follow-up period, patients who achieved pCR had a better 5 -year DFS with $22.8 \%$ of absolute difference. We also tested the survival difference between patients with residual invasive disease according to molecular subtypes. Carey et al. [15] reported that triple negative tumors tend to have a worse prognosis compared with those with ER-positive tumors among patients with residual disease. However, our data showed that the DFS of patients who have a residual disease is poor across all molecular subtypes. If pCR is not achieved, the luminal subtype is also more likely to relapse. This result suggests that failure to respond to NCT is indicative of a particularly poor outcome regardless of subtype.

To increase the pCR rate, it is reasonable to use different strategies according to different molecular subtypes. As shown in recent data of a $43-65 \%$ pCR rate by trastuzumab-containing NCT [29-31], incorporation of trastuzumab with neoadjuvant chemotherapeutics is a promising alternative for the HER2 subtype. These trials demonstrated significant improvement of DFS in patients who received neoadjuvant trastuzumab and suggest that the addition of trastuzumab to NCT should be considered for women with a HER2-positive tumor [29-31]. In the present study, HER2-positive tumors consisted of the luminal B (ER/PR positive and HER2 positive) and HER2 (ER/PR negative and HER2 positive) subtypes. Although influence of the ER status on responsiveness to neoadjuvant trastuzumab is unclear [27], adding trastuzumab to the neoadjuvant regimen can be considered in patients with both an ER- and HER2-positive tumor.

For the triple negative subtype, we still lack a target for this particularly poor prognosis group. Therefore, to maximize the pCR, extension of neoadjuvant cycles and new agents should be considered. Recent reports demonstrated that tumors from women with BRCA1 mutations were highly responsive to neoadjuvant cisplatin use [32, 33]. The triple negative subtype shares many histopathologic characteristics with BRCA-associated tumors, and a preclinical study demonstrated that a BRCA mutation carrying a tumor defective in DNA double-strand break repair was sensitive to cisplatin $[34,35]$. Beside a new chemotherapeutic, a clinical trial using a novel regimen based on the synthetic lethality strategy such as poly (ADP-ribose) polymerase inhibitors is warranted [36, 37].

It is even less likely that patients with luminal A will achieve a pCR. Clinicians often wonder whether additional NCT should be given to increase pCR. However, trials have shown that a tumor which was resistant to initial NCT had consistent resistance to extended cycles or a changed regimen with non-cross-resistant chemotherapeutics $[38,39]$. In addition, a delay in surgery and hormonal therapy resulting from non-effective NCT is problematic. We believe that if the intent is to achieve pCR, the luminal A subtype should not be considered for NCT, and offering initial treatment with surgery is optimal. If preoperative treatment is chosen to change local treatment options, the concurrent chemoendocrine regimen can be considered. Within the context of a clinical trial, a variety of approaches could be tested, including the use of a combination of new chemotherapeutics/endocrine agent and target agents such as angiogenesis inhibitors.

There are several limitations of this study. This is a retrospective study, and unrecognized biases might have influenced our results. Although our data suggested a strong association of pCR with breast cancer subtypes, the molecular subtype may not be independently associated with pCR because of the high correlation between the molecular subtype and the ER and HER2 status. In addition, the tumor grades and molecular subtypes are closely interlinked [27]. Because of this association, molecular subtypes might not replace the conventional clinicopathologic predictors such as ER, HER2 or tumor histologic grade with improving the prediction accuracy. To solve this issue, we need a large patient cohort that makes it possible to perform multivariate analysis with sufficient statistical power.

There is increasing evidence that ER-positive tumors consist of 2 biologically different subtypes and the proliferation index is the strongest parameter to distinguish luminal B from luminal A subtypes [11, 19, 20, 40]. Recent studies suggest that luminal A and B breast cancers appear to be distinguished by application of Ki-67 expression [11, 40], and Ki-67 expression identifies a subset of patients who could be sensitive to taxane-based treatment in an adjuvant setting $[11,41]$. In this retrospective study, we tried to separate 2 different luminal subtypes by Ki-67 expression with a cutoff point of $13.25 \%$ established by Cheang et al. [40], but only 27 tumors of a total of 143 luminal subtypes were able to evaluate Ki-67 expression. We separated luminal B tumors from luminal A by their expression of HER2 without incorporation of Ki-67 expression.

In conclusion, we reported additional evidence that the triple negative and HER2 subtypes of breast cancer are more sensitive to adriamycin/taxane-based NCT than the luminal subtype. Those patients who had a residual invasive disease showed a worse prognosis regardless of subtypes. To increase the pCR rate, it is reasonable to consider new approaches according to each subtype. The addition of trastuzumab for the HER2 or luminal B 
subtypes is a promising alternative strategy. For the triple negative subtype, extension of neoadjuvant cycles and neoadjuvant trial with a new chemotherapeutic such as cisplatin or other novel regimens should be considered. For the luminal A subtype, the conventional approach of early surgical intervention followed by adjuvant chemoendocrine therapy is optimal. To improve the surgical option, a neoadjuvant trial with concurrent chemoendocrine therapy can be considered.

\section{Acknowledgements}

This work was supported by the Brain Korea 21 Project for Medical Science, Yonsei University, and in part by a grant-in-aid from Novartis Korea Co., Astra Zeneca Korea Co., Dong-A Pharmaceutical Co., and Sanofi-Aventis Pharmaceutical Co.

\section{References}

1 Kaufmann M, von Minckwitz G, Bear HD, Buzdar A, McGale P, Bonnefoi H, Colleoni M, Denkert C, Eiermann W, Jackesz R, Makris A, Miller W, Pierga JY, Semiglazov V, Schneeweiss A, Souchon R, Stearns V, Untch M, Loibl S: Recommendations from an international expert panel on the use of neoadjuvant (primary) systemic treatment of operable breast cancer: new perspectives 2006. Ann Oncol 2007;18:1927-1934.

$\checkmark 2$ Fisher B, Brown A, Mamounas E, Wieand S, Robidoux A, Margolese RG, Cruz AB Jr, Fisher ER, Wickerham DL, Wolmark N, DeCillis A, Hoehn JL, Lees AW, Dimitrov NV: Effect of preoperative chemotherapy on local-regional disease in women with operable breast cancer: findings from National Surgical Adjuvant Breast and Bowel Project B-18. J Clin Oncol 1997;15:2483-2493.

3 Bonadonna G, Valagussa P, Brambilla C Ferrari L, Moliterni A, Terenziani M, Zambetti M: Primary chemotherapy in operable breast cancer: eight-year experience at the Milan Cancer Institute. J Clin Oncol 1998; 16:93-100.

4 Fisher B, Bryant J, Wolmark N, Mamounas E, Brown A, Fisher ER, Wickerham DL, Begovic M, DeCillis A, Robidoux A, Margolese RG, Cruz AB Jr, Hoehn JL, Lees AW, Dimitrov NV, Bear HD: Effect of preoperative chemotherapy on the outcome of women with operable breast cancer. J Clin Oncol 1998;16:2672-2685.

5 Rastogi P, Anderson SJ, Bear HD, Geyer CE, Kahlenberg MS, Robidoux A, Margolese RG, Hoehn JL, Vogel VG, Dakhil SR, Tamkus D, King KM, Pajon ER, Wright MJ, Robert J, Paik S, Mamounas EP, Wolmark N: Preoperative chemotherapy: updates of National Surgical Adjuvant Breast and Bowel Project Protocols B-18 and B-27. J Clin Oncol 2008; 26:778-785

6 Carey LA, Metzger R, Dees EC, Collichio F, Sartor CI, Ollila DW, Klauber-DeMore N, Halle J, Sawyer L, Moore DT, Graham ML: American Joint Committee on Cancer tumor-node-metastasis stage after neoadjuvant chemotherapy and breast cancer outcome. J Natl Cancer Inst 2005;97:1137-1142.
7 Mamounas EP: Neoadjuvant chemotherapy in operable breast cancer. Breast Care 2006 1:348-351.

-8 Perou CM, Sorlie T, Eisen MB, van de Rijn M, Jeffrey SS, Rees CA, Pollack JR, Ross DT, Johnsen H, Akslen LA, Fluge O, Pergamenschikov A, Williams C, Zhu SX, Lonning PE, Borresen-Dale AL, Brown PO, Botstein D: Molecular portraits of human breast tumours. Nature 2000;406:747-752.

$\checkmark 9$ Sorlie T, Perou CM, Tibshirani R, Aas T, Geisler S, Johnsen H, Hastie T, Eisen MB, van de Rijn M, Jeffrey SS, Thorsen T, Quist H, Matese JC, Brown PO, Botstein D, Eystein Lonning P, Børresen-Dale AL: Gene expression patterns of breast carcinomas distinguish tumor subclasses with clinical implications. Proc Natl Acad Sci USA 2001;98: 10869-10874.

10 Sorlie T, Tibshirani R, Parker J, Hastie T, Marron JS, Nobel A, Deng S, Johnsen H, Pesich R, Geisler S, Demeter J, Perou CM, Lonning PE, Brown PO, Borresen-Dale AL, Botstein D: Repeated observation of breast tumor subtypes in independent gene expression data sets. Proc Natl Acad Sci USA 2003; 100:8418-8423.

-11 Hugh J, Hanson J, Cheang MC, Nielsen TO, Perou CM, Dumontet C, Reed J, Krajewska M, Treilleux I, Rupin M, Magherini E, Mackey J, Martin M, Vogel C: Breast cancer subtypes and response to docetaxel in nodepositive breast cancer: use of an immunohistochemical definition in the BCIRG 001 trial. J Clin Oncol 2009;27:1168-1176.

12 Nielsen TO, Hsu FD, Jensen K, Cheang M, Karaca G, Hu Z, Hernandez-Boussard T, Livasy C, Cowan D, Dressler L, Akslen LA, Ragaz J, Gown AM, Gilks CB, van de Rijn M, Perou CM: Immunohistochemical and clinical characterization of the basal-like subtype of invasive breast carcinoma. Clin Cancer Res 2004;10:5367-5374

13 Cheang MC, Voduc D, Bajdik C, Leung S, McKinney S, Chia SK, Perou CM, Nielsen TO: Basal-like breast cancer defined by five biomarkers has superior prognostic value than triple-negative phenotype. Clin Cancer Res 2008;14:1368-1376.
14 Livasy CA, Karaca G, Nanda R, Tretiakova MS, Olopade OI, Moore DT, Perou CM: Phenotypic evaluation of the basal-like subtype of invasive breast carcinoma. Mod Pathol 2006;19:264-271.

15 Carey LA, Dees EC, Sawyer L, Gatti L, Moore DT, Collichio F, Ollila DW, Sartor CI, Graham ML, Perou CM: The triple negative paradox: primary tumor chemosensitivity of breast cancer subtypes. Clin Cancer Res 2007; 13:2329-2334.

$>16$ Wolff AC, Hammond ME, Schwartz JN, Hagerty KL, Allred DC, Cote RJ, Dowsett M, Fitzgibbons PL, Hanna WM, Langer A, McShane LM, Paik S, Pegram MD, Perez EA, Press MF, Rhodes A, Sturgeon C, Taube SE, Tubbs R, Vance GH, van de Vijver M, Wheeler TM, Hayes DF, American Society of Clinical Oncology/College of American Pathologists: American Society ofClinicalOncology/ College of American Pathologists guideline recommendations for human epidermal growth factor receptor 2 testing in breast cancer. Arch Pathol Lab Med 2007;131:1843.

17 Kaufmann M, Hortobagyi GN, Goldhirsch A, Schol S, Makris A, Valagussa P, Blohmer JW, Eiermann W, Jackesz R, Jonat W, Lebeau A, Loibl S, Miller W, Seeber S, Semiglazov V, Smith R, Souchon R, Stearns V, Untch M, von Minckwitz G: Recommendations from an international expert panel on the use of neoadjuvant (primary) systemic treatment of operable breast cancer: an update. J Clin Oncol 2006;24:1940-1949.

18 Mazouni C, Peintinger F, Wan-Kau S, Andre F, Gonzalez-Angulo AM, Symmans WF, Meric-Bernstam F, Valero V, Hortobagyi GN, Pusztai L: Residual ductal carcinoma in situ in patients with complete eradication of invasive breast cancer after neoadjuvant chemotherapy does not adversely affect patient outcome. J Clin Oncol 2007;25:2650-2655. 
-19 Rouzier R, Perou CM, Symmans WF, Ibrahim N, Cristofanilli M, Anderson K, Hess KR, Stec J, Ayers M, Wagner P, Morandi P, Fan C, Rabiul I, Ross JS, Hortobagyi GN, Pusztai L: Breast cancer molecular subtypes respond differently to preoperative chemotherapy. Clin Cancer Res 2005;11:56785685.

$\checkmark 20$ Desmedt C, Haibe-Kains B, Wirapati P, Buyse M, Larsimont D, Bontempi G, Delorenzi $M$, Piccart $M$, Sotiriou C: Biological processes associated with breast cancer clinical outcome depend on the molecular subtypes. Clin Cancer Res 2008;14:5158-5165.

-21 Bear HD, Anderson S, Smith RE, Geyer CE, Mamounas EP, Fisher B, Brown AM, Robidoux A, Margolese R, Kahlenberg MS, Paik S, Soran A, Wickerham DL, Wolmark N: Sequential preoperative or postoperative docetaxel added to preoperative doxorubicin plus cyclophosphamide for operable breast cancer: National Surgical Adjuvant Breast and Bowel Project Protocol B-27. J Clin Oncol 2006;24:2019-2027.

-22 Green MC, Buzdar AU, Smith T, Ibrahim NK, Valero V, Rosales MF, Cristofanilli M, Booser DJ, Pusztai L, Rivera E, Theriault RL, Carter C, Frye D, Hunt KK, Symmans WF, Strom EA, Sahin AA, Sikov W, Hortobagyi GN: Weekly paclitaxel improves pathologic complete remission in operable breast cancer when compared with paclitaxel once every 3 weeks. J Clin Oncol 2005;23:5983-5992.

-23 Gianni L, Zambetti M, Clark K, Baker J, Cronin $\mathrm{M}, \mathrm{Wu} J$, Mariani G, Rodriguez J, Carcangiu M, Watson D, Valagussa P, Rouzier R, Symmans WF, Ross JS, Hortobagyi GN, Pusztai L, Shak S: Gene expression profiles in paraffin-embedded core biopsy tissue predict response to chemotherapy in women with locally advanced breast cancer. J Clin Oncol 2005;23:7265-7277.

-24 Maur M, Guarneri V, Frassoldati A, Conte PF: Primary systemic therapy in operable breast cancer: clinical data and biological fall-out. Ann Oncol 2006;17:158-164.

25 Burcombe RJ, Makris A, Richman PI, Daley FM, Noble S, Pittam M, Wright D, Allen SA, Dove J, Wilson GD: Evaluation of ER, PgR, HER-2 and Ki-67 as predictors of response to neoadjuvant anthracycline chemotherapy for operable breast cancer. Br J Cancer 2005; 92:147-155.

-26 Petita T, Wilt M, Velten M, Millon R, Rodier JF, Borel C, Mors R, Haegele P, Eber M, Ghnassia JP: Comparative value of tumour grade, hormonal receptors, Ki-67, HER-2 and topoisomerase II alpha status as predictive markers in breast cancer patients treated with neoadjuvant anthracycline-based chemotherapy. Eur J Cancer 2004;40:205-211.
27 Bhargava R, Beriwal S, Dabbs DJ, Ozbek U, Soran A, Johnson RR, Brufsky AM, Lembersky BC, Ahrendt GM: Immunohistochemical surrogate markers of breast cancer molecular classes predicts response to neoadjuvant chemotherapy. Cancer 2010;116: 1431-1439.

28 Liedtke C, Mazouni C, Hess KR, Andre F Tordai A, Mejia JA, Symmans WF, GonzalezAngulo AM, Hennessy B, Green M, Cristofanilli M, Hortobagyi GN, Pusztai L: Response to neoadjuvant therapy and long-term survival in patients with triple-negative breast cancer. J Clin Oncol 2008;26:1275-1281.

29 Buzdar AU, Ibrahim NK, Francis D, Booser DJ, Thomas ES, Theriault RL, Pusztai L, Green MC, Arun BK, Giordano SH, Cristofanilli M, Frye DK, Smith TL, Hunt KK, Singletary SE, Sahin AA, Ewer MS, Buchholz TA, Berry D, Hortobagyi GN: Significantly higher pathologic complete remission rate after neoadjuvant therapy with trastuzum$\mathrm{ab}$, paclitaxel, and epirubicin chemotherapy: results of a randomized trial in human epidermal growth factor receptor 2-positive operable breast cancer. J Clin Oncol 2005;23: 3676-3685.

30 Gianni L, Eiermann W, Semiglazov V, Manikhas A, Lluch A, Tjulandin S, Zambetti M, Vazquez F, Byakhow M, Lichinitser M, Climent MA, Ciruelos E, Ojeda B, Mansutti M, Bozhok A, Baronio R, Feyereislova A, Barton C, Valagussa P, Baselga J: Neoadjuvant chemotherapy with trastuzumab followed by adjuvant trastuzumab versus neoadjuvant chemotherapy alone, in patients with HER2 positive locally advanced breast cancer (the NOAH trial): a randomised controlled superiority trial with a parallel HER2-negative cohort. Lancet 2010;375:377-384.

-31 Buzdar AU, Valero V, Ibrahim NK, Francis D, Broglio KR, Theriault RL, Pusztai L, Green MC, Singletary SE, Hunt KK, Sahin AA, Esteva F, Symmans WF, Ewer MS, Buchholz TA, Hortobagyi GN: Neoadjuvant therapy with paclitaxel followed by 5 -fluorouracil, epirubicin, and cyclophosphamide chemotherapy and concurrent trastuzumab in human epidermal growth factor receptor 2-positive operable breast cancer: an update of the initial randomized study population and data of additional patients treated with the same regimen. Clin Cancer Res 2007;13:228-233.

32 Byrski T, Huzarski T, Dent R, Gronwald J, Zuziak D, Cybulski C, Kladny J, Gorski B, Lubinski J, Narod SA: Response to neoadjuvant therapy with cisplatin in BRCA1-positive breast cancer patients. Breast Cancer Res Treat 2009;115:359-363.

-33 Silver DP, Richardson AL, Eklund AC, Wang ZC, Szallasi Z, Li Q, Juul N, Leong CO, Calogrias D, Buraimoh A, Fatima A, Gelman RS, Ryan PD, Tung NM, Nicolo AD, Ganesan S, Miron A, Colin C, Sgroi DC, Ellisen LF, Winer EP, Garbe JE: Efficacy of neoadjuvant cisplatin in triple-negative breast cancer. J Clin Oncol 2010;28:1145-1153.
34 Tassone P, Tagliaferri P, Perricelli A, Blotta S, Quaresima B, Martelli ML, Goel A, Barbieri B, Costanzo F, Boland CR, Venuta S: BRCA1 expression modulates chemosensitivity of BRCA1-defective HCC1937 human breast cancer cells. Br J Cancer 2003;88: 1285-1291.

35 Rottenberg S, Nygren AO, Pajic M, van Leeuwen FW, van der Heijden I, van de Wetering K, Liu X, de Visser KE, Gilhuijs KG, van Tellingen O, Schouten JP, Jonkers J, Borst P: Selective induction of chemotherapy resistance of mammary tumors in a conditional mouse model for hereditary breast cancer. Proc Natl Acad Sci USA 2007; 104:12117-12122.

>36 Farmer H, McCabe N, Lord CJ, Tutt AN, Johnson DA, Richardson TB, Santarosa M, Dillon KJ, Hickson I, Knights C, Martin NM, Jackson SP, Smith GC, Ashworth A: Targeting the DNA repair defect in BRCA mutant cells as a therapeutic strategy. Nature 2005; 434:917-921.

37 Rottenberg S, Jaspers JE, Kersbergen A, van der Burg E, Nygren AO, Zander SA, Derksen PW, de Bruin M, Zevenhoven J, Lau A, Boulter R, Cranston A, O'Connor MJ, Martin NM, Borst P, Jonkers J: High sensitivity of BRCA1-deficient mammary tumors to the PARP inhibitor AZD2281 alone and in combination with platinum drugs. Proc Natl Acad Sci USA 2008;105:17079-17084.

$>38$ Smith IC, Heys SD, Hutcheon AW, Miller ID, Payne S, Gilbert FJ, Ah-See AK, Eremin O, Walker LG, Sarkar TK, Eggleton SP, Ogston KN: Neoadjuvant chemotherapy in breast cancer: significantly enhanced response with docetaxel. J Clin Oncol 2002;20:14561466.

39 von Minckwitz G, Blohmer JU, Raab G, Löhr A, Gerber B, Heinrich G, Eidtmann H, Kaufmann M, Hilfrich J, Jackisch C, Zuna I, Costa SD, German Breast Group: In vivo chemosensitivity-adapted preoperative chemotherapy in patients with early-stage breast cancer: the GEPARTRIO pilot study. Ann Oncol 2005; 16:56-63.

40 Cheang MC, Chia SK, Voduc D, Gao D, Leung S, Snider J, Watson M, Davies S, Bernard PS, Parker JS, Perou CM, Ellis MJ, Nielsen TO: Ki67 index, HER2 status, and prognosis of patients with luminal B breast cancer. J Natl Cancer Inst 2009;101:736-750.

$\checkmark 4$ Penault-Llorca F, Andre F, Sagan C, LacroixTriki M, Denoux Y, Verriele V, Jacquemier J, Baranzelli MC, Bibeau F, Antoine M, Lagarde N, Martin AL, Asselain B, Roche $\mathrm{H}$ : Ki67 expression and docetaxel efficacy in patients with estrogen receptor-positive breast cancer. J Clin Oncol 2009;27:2809-2815. 